\title{
LA EXCEPCIÓN DE CONTRATO NO CUMPLIDO Y SU CONSAGRACIÓN EN EL CÓDIGO CIVIL CHILENO
}

\author{
"EXCEPTIO NON ADIMPLETI CONTRACTUS AND ITS \\ ESTABLISHMENT IN CHILEAN CIVIL CODE"
}

\section{Claudia Mejías Alonzo*}

\begin{abstract}
RESUMEN: La mayoría de la doctrina nacional considera que la excepción de contrato no cumplido se encuentra consagrada expresamente en nuestro Código Civil, en su artículo 1552. En este ensayo demostraremos que por razones históricas ella solo fue recogida implícitamente y, que la referida norma, basada en el Código Civil de Luisiana, consagra realmente la figura de la compensación de la mora, que es diferente a la institución de la excepción de contrato no cumplido, aunque ambas encuentren su fundamento en el principio de simultaneidad en el cumplimiento de las obligaciones.

Nuestro Código Civil solo recoge implícitamente a la excepción de contrato no cumplido. Aclarar ello tiene trascendencia para determinar su incidencia en los diversos efectos frente al incumplimiento contractual.
\end{abstract}

Palabras clave: Excepción de contrato no cumplido en el Código Civil nacional; compensación de la mora, artículo 1552 del Código Civil, incumplimiento contractual.

ABSTRACT: The majority of national doctrine considers exceptio non adimpleti contractus to be expressly established in article 1552 of our civil code. This essay will demonstrate that, for historical reasons, the aforementioned norm was only implicitly added. We argue that article 1552, based on the Louisiana Civil Code, actually establishes the model of default compensation, which differs from the institution of exceptio non adimpleti contractus, even though both are founded on the principle of simultaneity for fulfillment of obligations.

Our Civil Code only implicitly contains exceptio non adimpleti contractus. To clarify this point is of utmost importance in order to determine its incidence in the diverse effects stemming from breach of contract.

Key words: Exceptio non adimpleti contractus in national Civil Code; default compensation, article 1552 of the Civil Code, breach of contract.

Tradicionalmente se ha afirmado entre nosotros que la excepción de contrato no cumplido cuenta con una consagración expresa en nuestro Código Civil, en su artículo 1552. Sin embargo, de manera paulatina, es posible encontrar autores que afirman que ella solo cuenta con una consagración implícita.

\footnotetext{
Claudia Carolina Mejías Alonzo. Profesora de Derecho civil e Introducción al Estudio del Derecho, Escuela de Derecho, Pontificia Universidad Católica de Valparaíso. Correo electrónico: claudia.mejias@ucv.cl El presente artículo es resultado de la ejecución del Proyecto Fondecyt de Iniciación No 11110208, financiado por Fondecyt y forma parte del Proyecto Anillo de Investigación Asociativa en Ciencias Sociales, "Estudios Histórico-Dogmáticos de Derecho Patrimonial Privado: una mirada a los artículos de los Libros II y IV del Código Civil de Chile", SOC 1111, de CONICYT.
} 
Por nuestra parte, consideramos que la institución por razones históricas no fue acogida expresamente en nuestro Código Civil, sin perjuicio que pueda afirmarse un reconocimiento implícito a partir del propio artículo 1552 y otras disposiciones, que consagran el principio de simultaneidad en el cumplimiento de las obligaciones, donde ella encuentra su fundamento ${ }^{1}$. A esta conclusión arribamos teniendo en consideración los antecedentes históricos de la institución y las principales fuentes tenidas a la vista por don Andrés Bello.

La norma referida se encuentra ubicada dentro del Código Civil en su Libro IV, en el párrafo XII relativo a los efectos de las obligaciones, vinculada a las reglas de constitución en mora del deudor (artículos 1551 y 1552).

Tener claridad conceptual de la institución, así como sus orígenes, nos permitirán diferenciarla de la figura de la "compensación en mora". Esto es lo que, a nuestro juicio, prevé el artículo 1552 del Código Civil nacional.

No resulta baladí la distinción, sentado lo anterior podrá determinarse con precisión los efectos que la excepción de contrato no cumplido produce realmente y su verdadera injerencia en los mecanismos de tutela del acreedor lesionado, a los que tradicionalmente se le vincula: la ejecución forzada, la indemnización de perjuicios y la resolución por inejecución.

Con la finalidad de precisar los antecedentes de esta institución, hemos dividido este artículo en dos acápites, el primero de ellos referido a los antecedentes históricos de la institución y, el segundo, a la forma en que es recogida en nuestro Código Civil la excepción de contrato no cumplido. Finalizaremos con las conclusiones a las que arribemos a partir de este análisis ${ }^{2}$.

\section{ANTECEDENTES HISTÓRICOS DE LA EXCEPCIÓN DE CONTRATO NO CUMPLIDO}

Es en el derecho canónico donde encontramos los verdaderos antecedentes históricos de la excepción de contrato no cumplido. Con antelación no es posible reconocer la institución, sin perjuicio de advertirse atisbos de ella en el derecho romano, principalmente en la compraventa y en casos que, la doctrina moderna, vincula con la noción de sinalagma funcional; teniendo sí presente que la noción de causa, en el sentido de finalidad (causa final), no fue recogida en la jurisprudencia romana y que por ello, en rigor, no podemos hablar de los efectos propios que producen los contratos bilaterales, donde se inserta esta excepción ${ }^{3}$.

\footnotetext{
1 Sobre el fundamento y naturaleza jurídica de la excepción, véase Mejías Alonzo.

2 Nos interesa precisar que en este trabajo se ha decido no incorporar jurisprudencia nacional, que sobre el tema existe, porque ello será objeto de un desarrollo posterior, en otro artículo.

3 En este sentido, se hace notar que en las acepciones técnicas del término causa hay una cierta unidad estructural, se refieren a la eficiencia expresada en términos jurídicos -de justificación-, aquella que en términos modernos ha designado a la causa eficiente. Ciertamente en algún momento lo que se designó como res, en el sentido de finalidad empezó a ser denominada causa; siendo improbable que esté conectado con la noción de causa final. Cfr. Guzmán Brito (2005) pp. 276-277. En este sentido Cassin reconoce el sinalagma genético pero duda que los romanos hayan conocido el sinalagma funcional: lo que afecta al contenido de una obligación incide en la otra. La consideración a la finalidad que las partes perseguían con la celebración del contrato solo fue posible en los contratos de buena fe. Cfr. Cassin (1914) pp. 3-4, 42 y ss. Pillebout (1971) pp. 2-3. LÉvy y Castaldo (2010) p. 726.
} 
Si nos centramos en el derecho romano, la doctrina es coincidente en afirmar que no existe, con alcance general, la regla según la cual en las obligaciones bilaterales una parte no puede exigir a la otra, la ejecución de sus obligaciones, mientras ella no cumpla o no se encuentre llana a hacerlo.

No obstante, los autores advierten hipótesis que constituyen una aplicación particular de esta regla en los contratos de buena $\mathrm{fe}^{4}$. En este sentido Cassin afirma que el respeto a la buena fe lleva en varios textos romanos a rechazar la pretensión de uno de los contratantes, que reclama la prestación del otro, si no ha cumplido con la suya ${ }^{5}$. En sentido similar Guzmán, a propósito de la bona fides, sostiene que a partir de su inclusión el juez tiene libertad para apreciar y valorar cualquier comportamiento del deudor que sea contrario a la buena fe. Sin embargo, la jurisprudencia fue paulatinamente tipificando funciones concretas de la bona fides, destacando, entre las más importantes que: "sería contrario a la buena fe que una parte acreedora y al mismo tiempo deudora de la otra pretendiera el cobro íntegro de lo que le es debido sin estar dispuesta ella misma al pago íntegro de lo que debe; en consecuencia, se permite al juez operar una compensación de deudas que conduce a una condena por la diferencia” (Guzmán, 1996, p. 106) ${ }^{6}$.

Por lo anterior, aunque circunscrito a la compraventa -contrato consensual y de buena fe por excelencia- se afirma, por los autores, que el comprador se hallaba protegido judicialmente en virtud de la cláusula ex fide bona que hacía innecesario contar con la excepción de contrato no cumplido ${ }^{7}$.

A continuación nos referiremos a los principales textos que, en el derecho romano, son considerados como manifestaciones de la excepción de contrato no cumplido. Ellos se encuentran en el contrato de compraventa o bien, vinculados a él, ya que, como adelantábamos, la opinión dominante en la doctrina es que el vendedor, a quien se le reclama la entrega

\footnotetext{
4 Cassin (1914) p. 1. Gastaldi (1995) pp. 46-47. Planiol y Ripert (1952) vol. 7, pp. 606-607. En este sentido Cruz Moreno afirma "parece que se originó en Roma, aunque la denominación fue posterior, como cláusula introducida en la compraventa, por la que el vendedor podía no realizar la entrega de la cosa vendida hasta que no se le pagase el precio [...]. Más adelante el Pretor, tomando como ejemplo esa defensa convencionalmente creada, acabaría reconociéndola por ley”. Expresa sí la autora que en el derecho romano no se llegó a fraguar una idea acabada de la exceptio. Cruz Moreno (2004) pp. 13-14.

La doctrina también ha sostenido que encuentra su origen en el derecho romano, en la noción de buena fe, gracias a la influencia y el resultado de una cláusula estándar, introducida en la solicitud del demandado, en el procedimiento formulario y que fue conocida como la "exceptio doli". Zimmermann y Whittaker (2000) pp. 16 y ss.

5 Cassin (1914) p. 6. El autor precisa sí que aún en estos casos la negativa de ejecución tuvo características distintas a las que hoy se reconocen a la excepción de contrato no cumplido, propias del procedimiento romano.

Persico, por su parte, afirma que la expresión "exceptio non adimpleti contractus" no se encuentra en las fuentes de derecho romano, aunque este remedio era conocido con el nombre de "exceptio doli" y "exceptio mercis non traditae". Persico (1955) p. 1.

6 Guzmán Brito (1996) p. 106, más adelante, p. 141. Es fácil advertir que de esta aplicación surge la vinculación histórica entre la excepción de contrato no cumplió y la compensación.

7 Cfr. Zimmermann y Whittaker (2000) p. 801. Schulz (1960) p. 508. Precisa el autor que, por regla general, la fórmula venditti contiene la adición a la intentio, de la expresión ex fide bona. Su significación ordinaria fue que el juez debía decidir conforme a la buena fe. En la época en que la fórmula venditti fue creada, el contrato no formal de compraventa aún no era reconocido por el ius civile, de manera que solo podía fundarse en la buena fe. En tiempos clásicos el significado de la cláusula es diferente. Ya no constituyó la base de la acción sino que pretendió determinar la medida y alcance del contrato (pp. 34-35).
} 
de la cosa -por el ejercicio de la actio empti-, puede oponerse a la demanda si el comprador no ha pagado u ofrecido pagar el precio. Del mismo modo, el comprador puede oponerse a la acción del vendedor -ejercicio de la actio venditi- si este no ha pagado o entregado la cosa ${ }^{8}$.

a) En el texto de las Instituciones de Justiniano (Inst. 2, 1, pr. $41^{9}$ ) se establece que aun cuando el vendedor haya entregado la cosa no la adquiere el comprador si a su vez no ha entregado el precio. Esta norma ha sido entendida como una garantía para el vendedor $y$, en una de sus interpretaciones, que el pago del precio es condición necesaria para exigir la entrega de la $\operatorname{cosa}^{10}$. En este sentido D'Ors señala que en estos casos "el comprador puede considerarse propietario de la res tradita frente a todos, pero no frente al vendedor (...), que puede oponerle la exceptio (o replicatio) doli. Este efecto relativo fue aparentemente absolutizado por Justiniano (Inst. 2, 1, 41), al decir que el comprador no adquiere la propiedad si no paga o no da garantía" (D'Ors, 1981, pp. 230-231) ${ }^{11}$.

En el Digesto (D. 21, 1, 31, 8) Ulpiano, en los Comentarios al Edicto de los Ediles Curules, cita a Marcelo, quien afirma, que no puede uno de los dueños a través de la acción de compra conseguir la entrega del vendedor si previamente no ha pagado el precio porque él retiene en calidad de prenda, lo que vendió ${ }^{12}$. En el mismo sentido, se encuentra el texto

8 Guzmán (1996) p. 141. Pillebout (1971) p. 3. Viario (2008) p. 789. La autora expresa, en páginas siguientes, que sin perjuicio de la consecuencia práctica de evitar que una de las partes sea condenada a cumplir con su prestación si el otro no lo ha hecho con la suya, se discute si estamos ante una propia y verdadera excepción o bien ante una verdadera condición de la acción.

La doctrina se refiere también a otros contratos consensuales en el derecho romano, hoy sinalagmáticos por excelencia: 1) La locatio conductio. Se consideran manifestaciones de la excepción de contrato no cumplido la facultad reconocida al locator o conductor, respectivamente, de oponerse al cumplimiento si el otro no había cumplido, aunque en rigor figura vinculada con el derecho de retención y a la buena fe que debe guiar a estos contratos, véase D. 14, 2, 2 pr.; D. 19, 2, 19, 3 y C. 4, 65, 14; sin perjuicio de que se discuta por la doctrina, también, respecto de ellos el sinalagma funcional. 2) El contrato de sociedad, la aplicación de la excepción de contrato no cumplido también descansa en la afirmación de que el jurista romano consideraba, que se oponía a la buena fe, que un contratante solicitara el cumplimiento del otro, si no había dado cumplimiento o demostraba estar pronto a hacerlo, véase D. 17, 2, 63 pr. y otras manifestaciones del ejercicio de la actio pro socio. 3) El contrato de mandato, básicamente tratándose de reglas en las que por ser remunerado, se equiparaba al contrato de arrendamiento, o bien, en hipótesis de ejercicio de la actio ex mandati, véase D. 17, 1, 1, 4; D. 17, 1, 6 pr. Cfr. Viario (2008) pp. 129 y ss.

9 "Sed si quidem ex causa donationis aut dotis aut qualibet alia ex causa tradantur, sine dubio transferuntur: [\$41] venditae vero res est traditae non aliter emtori acquiruntur, quam si is venditori pretium solverit, vel alio modo ei satisfacerit, veluti expromissore aut pignore dato (...)".

10 Viario (2008) pp. 56 y ss. Nicolas (1872) pp. 88-89.

11 D’Ors (1981) pp. 230-231. En este dirección Arangio Ruiz hace presente que no se trata de una regla clásica sino que aparece en el derecho romano vulgar postclásico, Cfr. Arangio Ruiz (1954) pp. 276-308. Reconoce también esta facultad del vendedor como manifestación de la excepción de contrato no cumplido, CAMUs (1942) p. 268.

En similar sentido Ghestin afirma que solo en la compraventa de manera cierta tuvo aplicación esa institución, ya a través de la exceptio mercis non traditae o una excepción de dolo. Cfr. GHestin (2001) p. 3.

12 "Idem Marcellus ait, non posse alterum ex dominis consequi actione ex emto, ut sibi pro parte venditor tradat, si pro portione pretium dabit; et hoc in emtoribus servari oportere ait, nam venditor pignoris loco quod vendidit, retinet, quoad emtor satisfaciat".

Precisamos que el comentario de Ulpiano al Edicto de Ediles Curules es al Libro I. Cabe tener presente, además, que esta regla puede ser considerada una particularidad del Edicto de los Ediles Curules, que como se sabe en época clásica no estaba generalizada. 
del Digesto (D. 19, 1, 13, 8) ${ }^{13}$ en el que Ulpiano afirma que el comprador debe ofrecer el pago del precio para poder ejercitar su acción, haciéndose presente que el vendedor puede retener en prenda lo que vendió ${ }^{14}$.

A partir de estos textos, parte de la doctrina considera que en el derecho romano se llegó al mismo resultado, que si se hubiese contado con la excepción de contrato no cumplido, mediante la figura de la retención de la cosa vendida ${ }^{15}$, partiendo de la premisa que se estaba ante obligaciones independientes ${ }^{16}$. Lo anterior se debe a que el vendedor detenta la cosa a título de prenda, de manera que mientras la deuda garantizada no fuese cumplida o se extinguiera de otro modo, el acreedor pignoraticio podía oponer una exceptio a la acción del pignorante; extinguiéndose la obligación, la retención posesoria carece de causa y era procedente la acción de repetición ${ }^{17}$.

Los anteriores pasajes se justifican porque en la compraventa la obligación de entregar la cosa y la obligación de pagar el precio, salvo acuerdo entre las partes, eran simultáneas. Por esto, no se está obligado a entregar la cosa si no se ha recibido el precio y, lo mismo, a la inversa, con la finalidad de garantizar el simultáneo cumplimiento del contrato ${ }^{18}$. En definitiva lo anterior descansa en el derecho romano en el principio de la bona fides ${ }^{19}$.

13 "Offerri pretium ab emptore debet quum ex empto agitur, et ideo et si pretti partem offerat, nondum est ex emto action; venditor enim quasi pignus retinerepotest eam rem, quam vendidit”.

14 A propósito de la compraventa, Silvia Viaro menciona otros textos vinculados al reconocimiento de la excepción de contrato no cumplido y las principales críticas formuladas, tratándose de la excepción de incumplimiento a favor del vendedor y la excepción de incumplimiento a favor del comprador. Viario (2008) pp. 816-836; 845-854.

15 Ourliac y De Malafosse (1960) p. 434. Ghestin (2001) p. 3.

16 Cfr. Viario (2008) pp. 70-71; 75 y ss.

Se mencionan, además, otros ejemplos, tratándose de los vicios ocultos, el comprador conserva el bien hasta que el vendedor le restituya el precio, le indemnice los perjuicios causados por la cosa y le reembolse los gastos hechos en ella (D. 21, 1, 29, 3; D. 30, 1). El depositario y el comodatario tienen derecho de retención respecto de los créditos nacidos del contrato.

17 D’Ors (1981) p. 476. Viario (2008) pp. 99 y ss.

18 Hernández Tejero (1978) pp. 234-235. Precisa D’Ors que una vez que la Jurisprudencia llegó a admitir la perfección del contrato por el simple consentimiento, las obligaciones de entregar la cosa y pagar el precio que en él se originan se presentaron como simultáneas. Ninguno de los contratantes podía exigir la prestación del otro sin ofrecer, al mismo tiempo, el cumplimiento de la suya. La facultad del comprador de rechazar la pretensión del vendedor es una generalización de la exceptio mercis non traditae que el Edicto daba contra el banquero mediador de una subasta, que reclamaba el precio estipulado del comprador (Gai. 4. 126a), D'Ors (1981) pp. 548-549. Invocando el mismo texto como una manifestación de la excepción de incumplimiento a favor del comprador, véase Viario (2008) pp. 107 y ss. Schulz (1960) p. 459.

19 En este sentido Torrent afirma "La compraventa es un contrato sinalagmático, y en principio, salvo pacto en contrario, las dos prestaciones deben ejecutarse simultáneamente, que si en Derecho moderno este principio de simultaneidad de la ejecución se basa en la teoría de la causa (en cuanto la causa para cada parte contratante está en la contraprestación de la otra parte) en Derecho romano más bien se recurre al principio de la bona fides en virtud del cual las partes deben abstenerse de actuaciones dolosas. En principio, por tanto, la adquisición del comprador es independiente del pago del precio, puesto que este puede aplazarse, pero desde la época de Labeón (principios del siglo I d.C.) la buena fe exigía que el comprador no podía exigir la entrega de la cosa mientras no pague el precio, y en el sigo II d.C (Marcelo, Scaevola) triunfa el principio de que el comprador no puede exigir la entrega de la cosa mientras no pague el precio; es más se reconoce al vendedor como una especie de prenda (quasi pignoris loco) sobre la cosa vendida hasta que el comprador no haya pagado completamente el precio (...)", TORRENT (1995) p. 457. 
b) A propósito de la exceptio doli. En principio con su ejercicio, se concedía una acción y una excepción, vinculada con el dolo incurrido en el acto mismo del que depende el derecho del actor; en definitiva el pretor lo considera vicio del acto jurídico y de la obligación que de él deriva ${ }^{20}$.

En el texto de las Instituciones (Inst. 4, 13, pr. 1) ${ }^{21}$, relativo a las excepciones, resulta plausible que el pretor además, es llamado a hacer valer la equidad y la justicia natural, por ello se amplía el ejercicio de la exceptio doli y deviene en un medio de defensa para resistir cualquier pretensión que el pretor encuentre contraria a la equidad natural ${ }^{22} \mathrm{o}$, como ha afirmado parte de la doctrina, contrario a la buena fe y a la lealtad ${ }^{23}$. De esta forma se alude a la exceptio doli en sentido general que puede referirse a cualquier defensa fundada en la equidad y la buena fe que permite evitar un ejercicio abusivo de una acción ${ }^{24}$.

Sin perjuicio de lo expresado precedentemente, y como anticipáramos, la mayoría de la doctrina se inclina por afirmar que la excepción de contrato no cumplido fue admitida de forma general, para toda clase de contratos bilaterales, solo en el derecho canónico, vinculada en sus orígenes con otra institución sinalagmática, la resolución.

En este contexto, es necesario traer a colación los juramentos promisorios, una importante creación de la jurisprudencia canónica. En la Edad Media los juramentos tuvieron un rol preponderante y este en particular era un contrato unilateral, formal y abstracto que, pudiendo aplicarse a toda clase de objetos, daba lugar a una nueva obligación ${ }^{25}$. La frecuencia de estos juramentos condujo en la práctica a abusos, intentándose por la jurisprudencia prevenirlo a través de distintos medios, uno de ellos, las condiciones tácitas, aun cuando el juramento fuese independiente de toda causa ${ }^{26}$.

20 En esta dirección Burdese sostiene hay dos casos que tradicionalmente se vinculan con el dolo, como vicio de la voluntad y cualquier otro comportamiento considerado doloso, Burdese (2006) p. 94. Los hermanos Mazeaud vinculan los antecedentes históricos de la institución con la excepción de dolo. El desarrollo posterior de los canonistas lo derivan de esta misma excepción. Cfr. Mazeaud et al. (1998) pp. 1163-1170.

21 Sequitur, ut de exceptionibus dispiaciamus. Comparatae sunt autem exceptiones defendendorum eorum gratia, cum quibus agitur; saepe enim accidit, ut, licet ipsa persecution, qua actor experitur, iusta sit, tamen iniqua sit adversus eum, cum quo agitur.

En el mismo sentido suele citarse D. 44, 4, 1, 1.

22 Milone (1882) pp. 59-65. Precisa, más adelante, el autor que la generalidad de la exceptio doli puede entenderse en dos direcciones, una como una excepción genérica al servicio de la equidad y, la otra, como una excepción genérica que permite suplir cualquier otra excepción, fundada sí en la equidad. En definitiva las dos direcciones pueden ser reconducidas a una sola (pp. 74-75).

Se han citado otros textos con referencia a la exceptio doli, C. 8, 44, 5, aunque la doctrina ha puesto de relieve que probablemente el texto se encuentra interpolado.

23 Jörs y Kunkel (1937) p. 370. Labruna (2006) p. 127.

24 En este sentido Guzmán afirma que la exceptio doli tenía un alcance general, en el sentido que resultaba oponible cuando no había otra excepción que alegar. Guzmán Brito (1996) p. 154.

25 Esmein (1888) pp. 248 y ss. Cassin (1914) pp. 42 y ss., el autor advierte la diferencia entre esta clase de juramentos y los confirmatorios que conformaban una obligación preexistente.

A propósito de la stipulatio se considera la exceptio doli generalis, como el remedio que permite al deudor oponerse a la acción del acreedor, probando la falta de entrega de dinero y con ello sostener la ausencia de causa de su promesa de pagarlo, testimonio de ello se encuentra en Gaio 4, 116a. Cfr. PetrucCi (2006) pp. 243-245.

26 Cassin (1914) p. 42 y ss. EsMein (1888) p. 248. 
El principio de las condiciones sobreentendidas recibió una clara aplicación en las Decretales del Papa Inocencio III y, posteriormente, con la difusión de los Decretales de Gregorio IX, siendo Bonifacio VIII quien decantó la fórmula definitiva del Canon Frustra (1298). En rigor el antecedente directo de la excepción de contrato no cumplido lo situamos en la Summa sobre el Decreto de Graciano, de Hugo de Pisa, en el siglo XII, ya que en ella se formuló por primera vez el adagio "Fides non servanda est ei frangit fidem", que consagra el principio de respeto de las convenciones y que implicaba que si una parte no respetaba su palabra, la otra no era obligada a respetar la suya ${ }^{27}$. Si este principio era violado, el contratante inocente gozaba de dos mecanismos de tutela: por una parte podía acudir al juez para que impusiera la ejecución de lo prometido y por otra, si lo anterior por cualquier motivo no le interesaba, podía pedir la liberación de toda promesa que hubiese hecho: " $f$ des non est servanda ci qui frangenti fidem" 28 .

Como han puesto de relieve parte de la doctrina, concebida en los términos descritos, permitiría justificar la excepción de contrato no cumplido en cualquier contrato con obligaciones recíprocas, ya que el deudor no estaría obligado a cumplir con su prestación hasta que el acreedor no haya cumplido con su promesa, sin perjuicio de constituir, además, el antecedente histórico de la resolución. Se advierte que la excepción de contrato no cumplido tiene un carácter solo provisorio en la relación obligatoria, de suspensión del cumplimiento de la prestación, ya que en principio se quedaba vinculado indefinidamente, hasta que una de las partes decidiera cumplir, a menos que operara la resolución ${ }^{29}$.

Su denominación es obra de los Postglosadores. Bartolo es quien generaliza el texto del Digesto, significativo tratándose de los contratos sinalagmáticos (D. 50, 16, 19) ${ }^{30}$. Sus sucesores ya en el siglo XV comienzan a estudiar esta institución denominada "exc. non implementi, implementi non secuti, impletionis ex parte agentis non secutae, non impleti contractus, modi non servanti" 31 .

\footnotetext{
27 A partir de este principio es elevado a norma jurídica el principio moral de respecto de las convenciones. En la misma dirección Levy (2010) p. 727. Cabe considerar que la doctrina ha puesto de manifiesto la influencia que el derecho canónico ha tenido en el derecho secular, entre otras se menciona la "Bona Fides", entendida como la creencia legítima de que el acto que se está realizando es lícito y legítimo, la idea que está detrás afirma el profesor Salinas Araneda "es que la verdad debe resplandecer siempre en la conducta del cristiano y, por lo mismo, en la apreciación de los propios derechos, de manera que la ausencia de bona fides comporta un pecado incompatible con la buena fe". Salinas Araneda (2006) p. 30.

28 Cfr. Zimmermann (2001) p. 142. Zimmermann(1990) p. 801. Levy (2010) p. 868. Cassin (1914) pp. 42 y ss. Alonso Pérez (1967) pp. 17-18. Pillebout (1971) p. 5. Álvarez Vigaray (1986) (Granada, Editorial Comares) pp. 28-31. Melich-Orsini (1997) pp. 62-64. Dell'Aquila (1981) pp. 48-63. Boyer (1924) pp. 224-25, 256-257. Capitant (1930) pp. 143-144, 257-258.

Por mucho tiempo, incluso, el fundamento de la excepción de contrato no cumplido se encontró en la denominada condición resolutoria. Negándose por autores franceses, como veremos, la necesidad misma de la exceptio ya que su función podía ser cubierta por la resolución. Persico (1955) pp. 14-15.

En Alemania en cambio, en el Medioevo, la exceptio non adimpleti contractus tuvo una particular importancia debido a la falta de una acción general de resolución. Persico (1955) p. 15

29 Véase Mejías Alonzo (2011) pp. 63 y ss. Levy (2010) p. 727.

30 Tratándose de la excepción de contrato no cumplido, en concreto véase comentario de Bartolo a la ley Offerri Precium. De Saxoferrato (1996) p. 119.

31 Cassin (1914) pp. 46 y ss.
} 
Situados los orígenes de la excepción de contrato no cumplido en el derecho canónico, nos interesa precisar cómo ella ha sido recogida en el Código Civil nacional y en ello ahondaremos en el apartado siguiente.

\section{LA EXCEPCIÓN DE CONTRATO NO CUMPLIDO Y SU CONSAGRACIÓN EN EL CÓDIGO CIVIL CHILENO}

Tradicionalmente, como se ha indicado, la doctrina nacional acude al artículo 1552 del Código Civil para referirse a la excepción de contrato no cumplido ${ }^{32}$. Solo excepcionalmente se ha postulado que la institución no cuenta con una consagración expresa en el Código Civil teniéndose en consideración, principalmente, el hecho de que el Code Civil francés no la prevé.

Con la finalidad de dilucidar si el artículo 1552 consagra realmente esta institución nos parece relevante tener en cuenta las fuentes de esta disposición y constatar cómo en ellas resulta recogida la excepción de contrato no cumplido. Precisado lo anterior, resulta pertinente y relevante caracterizar la figura de la "compensación de la mora" porque parte de la doctrina nacional ha sostenido que es ella, en rigor, lo que regla el artículo 1552. Finalmente nos referiremos a la forma en que es recogida la institución en nuestro Código Civil.

\subsection{Antecedentes inmediatos de la eXCepCión de CONTRATO NO CUMPLido EN el Código Civil chileno}

Para poder conocer y determinar las fuentes que don Andrés Bello tuvo en vista para la redacción de este libro podría resultar relevante examinar las referencias a otras normas, que puso a los artículos, en los diferentes proyectos de Código Civil ${ }^{33}$. Sin embargo, en esta materia no es posible encontrar notas que nos permitan inferir alguna de las fuentes que haya podido considerar. Sí podemos precisar que la doctrina especializada ha puesto énfasis que en el Libro IV del Código la influencia ha sido principalmente francesa, el Code y Pothier ${ }^{34}$, sin perjuicio de mencionarse otras posibles fuentes, entre ellas el proyecto de García Goyena ${ }^{35}$.

\footnotetext{
32 Por todos véase Abeliuk (2010) pp. 941 y ss.

33 En este sentido Guzmán Brito (1982) pp. 408-409. Sin embargo, el autor precisa que "es imposible reconocer la existencia de un criterio único aplicado por Bello a sus notas”, además, él mismo reconoce una ausencia de un método uniforme.

34 Guzmán Brito (2009) p. 57.

Lira Urquieta, por su parte atribuye una importancia excepcional al Proyecto de García Goyena, véase LiRA UrquiETA (1956) pp. 75 y ss. Entre otras razones que menciona el autor, afirma que tuvo un valor considerable pues presentaba un panorama completo de la legislación civil hasta entonces conocida. Sin embargo, sostiene: "En la teoría de los actos jurídicos parece razonable suponer que la influencia determinante fue la francesa, sobre todo la de Pothier. Las disposiciones del Proyecto Español no son semejantes, por lo general, a la de nuestro Código Civil” (pp. 43-46). Guzmán Brito (2000) p. 371.

35 GuZmán (2000) pp. 370. Lira (1956) pp. 75 y ss.
} 
La doctrina nacional que se ha referido expresamente a esta materia suele indicar, mayoritariamente, como fuentes inmediatas de la disposición el Código Civil francés, porque es conocida su clara influencia en el libro IV ${ }^{36}$.

Con una opinión distinta, Luis Claro Solar afirma que el artículo 1552 no tuvo como antecedente disposición expresa del Código francés, sino que "siguiendo los preceptos del Derecho romano, se inspiró en las reglas especiales que las Partidas consignaban para la compraventa y las promisiones en general, en las cuales se hallaba en realidad, consultado el cumplimiento simultáneo de las obligaciones recíprocas" ${ }^{37}$. Ciertamente la fuente que predominó en la redacción del Código Civil fue el código de las Siete Partidas ${ }^{38}$, mas no encontramos en él disposición equivalente al tenor del artículo 1552 del Código Civil, sí en cambio, como afirma Claro Solar, reglas que son manifestaciones del principio de cumplimiento simultáneo, fundamento de la excepción de contrato no cumplido ${ }^{39}$.

Se ha sostenido también que este precepto ha sido redactado sobre la base del artículo 1907 del Código de Luisiana ${ }^{40}$ o bien del Proyecto de García Goyena.

Previo a centrarnos en las fuentes enunciadas, consignamos que solo en el Proyecto de Código Civil del año 1853, en su artículo 1731, puede encontrarse una norma equivalente al actual artículo 1552, norma que dispone "En los contratos bilaterales, ninguno de los contratantes está en mora dejando de cumplir lo pactado, miéntras el otro no lo cumple por su parte, o no se allana a cumplirlo en la forma i tiempo debidos" ${ }^{41}$. Cabe tener en consideración que tratándose de la regulación general de la mora, ella ya está presente en el artículo $5^{\circ}$, del Título XI, del Proyecto de Código Civil sobre contratos y obligaciones convencionales de los años 1842-184542.

\section{A) Los antecedentes en el Código Civil francés}

En el Código Civil francés no existe un texto que consagre en términos generales la excepción de contrato no cumplido, solo existen manifestaciones de ella en contratos especiales, como veremos más adelante.

La ausencia de una consagración expresa, de la excepción de contrato no cumplido, se debe a la doctrina del siglo XVI, que influyó en los antecedentes del Código Civil francés. En efecto, con el renacimiento de los estudios del derecho romano se pretendió darle a las leyes romanas su sentido natural, lo más ajustado a las fuentes, rechazándose las construcciones de los postglosadores. Con Cujas triunfa el método exegético e histórico. Debido a que la excepción de contrato no cumplido, como tal, no fue conocida en el derecho romano, no importó una generalización de la misma, no obstante, conocerse los textos romanos que confieren al

\footnotetext{
36 Por todos véase GuZmán (1982) pp. 421 y ss.

37 Claro Solar (1978) p. 786.

38 Por todos, Guzmán (1982) p. 414.

39 En este sentido P. 5, 6, 5. P. 5, 32, 5. P. 5, 1, 12.

40 Alcalde Rodríguez (2003) p. 84. Alcalde Silva (2011) p. 51.

41 Bello (1890) p. 432.

42 Figura posteriormente la regulación en el artículo 96 del Proyecto del año 1847, que corresponde a la segunda edición del libro; y en el artículo 1730 del Proyecto de 1853 y del Proyecto Inédito.
} 
vendedor el derecho a retener la cosa como en prenda ${ }^{43}$. Sí nos parece importante destacarque es Cujas quien precisa que el que actúa debe ejecutar su prestación primero, de lo contrario la equidad se vería vulnerada si una de las partes pudiera obtener las ventajas prometidas sin realizar el sacrificio correspondiente, consentido por ella ${ }^{44}$.

En la jurisprudencia francesa, siglos XVI y XVII, se crean medios importantes de protección de los contratantes, que hicieron innecesario el empleo de la exceptio non adimpleti contractus, limitando su campo de aplicación. Es el caso del derecho de resolución por inejecución, aplicable a todos los contratos sinalagmáticos y el privilegio del vendedor de muebles y edificios ${ }^{45}$.

Tratándose de la doctrina, que se considera precursora del Código Civil francés, se advierte una expresa adhesión al principio de ejecución simultánea, que es donde encuentra su fundamento la excepción de contrato no cumplido ${ }^{46}$. Así, Pothier afirma en su tratado de compraventa, a propósito de la actio ex empto, que el comprador no puede intentar esta acción contra el vendedor si no ofrece pagar el precio convenido, o todavía no lo ha pagado, porque no puede admitirse que demande al vendedor para satisfacer sus compromisos, si él no ha satisfecho los suyos ${ }^{47}$. A propósito de la actio venditi, señala que la principal obligación que contrae el comprador consiste en el pago del precio convenido, y en aquellos contratos que no tienen un plazo, el vendedor puede emplear esta acción en contra del comprador, ofreciendo entregar la cosa vendida, si no lo ha hecho ${ }^{48}$. En similar sentido Domat precisa que en las convenciones, el compromiso de uno es el fundamento del compromiso del otro y que su primer efecto es que cada uno de los contratantes puede obligar al otro a ejecutar su compromiso, ejecutando el suyo por su parte, sea que la ejecución deba hacerse de una y otra parte al mismo tiempo ${ }^{49}$.

Atendido lo anteriormente expuesto, se advierte que en el Código Civil francés no existe un texto que consagre en términos generales la excepción de contrato no cumplido. Sin embargo, nos referiremos a las principales manifestaciones de la misma, indicadas por

43 Cujacci (1758) pp. 672-673. Cfr. Cassin (1914) pp. 83-87. Manifestación de ello, véase en Delvincourt (1824) pp. 136-137. Aubry, C.; Rau, C. (1871) pp. 360-365, 396-397.

44 CujACCI (1758) pp. 672-673. Habiéndolo afirmado previamente Cassin, quien además precisa que para Cujas la excepción de contrato no cumplido no fue más que una variante de la actio doli. Cassin (1914) pp. 86-87.

45 Cassin (1914) pp. 93 y ss. En similar dirección Lévy, refiriéndose al derecho antiguo francés, afirma que en los países de derecho escrito, sin referencia la cláusula non adimpleti contractus o al principio Frangenti Fidem, en los siglos XII y XIII, por la vía de la resolución se subsumía su hipótesis, en los cuatro contratos consensuales del derecho romano. De forma similar, en los países de coutumes, en los contratos nominados e innominados. Más adelante afirma que además, hay que tener en consideración las garantías en el derecho francés antiguo. Conforme a las costumbres, el vendedor podía retener la cosa vendida, es decir, se encontraba facultado a no cumplir con su prestación mientras el comprador no cumpliera la suya -pagar el precio- o lo ofreciera. De esta forma la excepción de contrato no cumplido es un corolario del derecho de retención, Levy (2010) pp. 725, 727.

46 Respecto del fundamento de la excepción de contrato no cumplido, véase Mejías (2012). De la Prida (2012) pp. 51 y ss.

47 Pothier (1821-1824) pp. 44-45 (No 63). En el mismo sentido p. 46 (No 66).

48 Pothier (1821-1824) p. 219 (No 279-280).

49 Doмат (1835) pp. 134-135. 
la doctrina, a partir de las cuales ella y la jurisprudencia han extendido su aplicación más allá de estas normas:

a) En materia de compraventa, artículos 1612, 1613, 1651,165350. Conforme al primero de ellos, el vendedor no está obligado a entregar la cosa si el comprador no ha pagado el precio, si el contrato es de ejecución simultánea. Tampoco se encuentra obligado a la entrega, si la situación patrimonial del deudor (quiebra o insolvencia) conlleva a una pérdida inminente de perder el precio, a menos que el comprador otorgue garantías (art. 1613).

Reafirma la ejecución simultánea de las obligaciones el artículo 1651 que dispone que, salvo pacto en contrario, el pago del precio debe efectuarse al momento de la entrega. En la misma dirección, la facultad del comprador de suspender el pago del precio si fuese perturbado o tuviese el justo temor de serlo, por el ejercicio de una acción hipotecaria o reivindicatoria, hasta que el vendedor haga cesar la turbación (art. 1653).

b) En el contrato de permuta, artículo $1704^{51}$. Si uno de los contratantes, que recibe la cosa entregada en permuta, prueba que ella no era de propiedad del otro contratante, no está obligado a entregar lo que prometió sino solo a devolver lo que recibió.

c) En el contrato de arrendamiento, artículo $1749^{52}$, los arrendatarios no pueden ser expulsados por el arrendador si previamente no les ha pagado los daños y perjuicios que procedan según la ley.

d) Finalmente tratándose del depósito oneroso, artículo $1948^{53}$. Se faculta al depositario para retener el depósito hasta el completo pago de lo que se le deba en razón del depósito.

A partir de lo expuesto nos parece que la influencia del Code y la doctrina que le sirvió de antecedente no fue determinante para que se recogiera entre nosotros la excepción de contrato no cumplido, ni influyó en la redacción del artículo 1552 de nuestro Código Civil. El tratamiento de la excepción de contrato no cumplido fue ocasional y básicamente circunscrito al principio de ejecución simultánea de las obligaciones en el contrato bilateral por excelencia, la compraventa.

\section{B) Los antecedentes en el Proyecto de García Goyena}

Es sabido que dentro de las fuentes que inspiraron a don Andrés Bello se encuentra el libro titulado "Concordancias, motivos y comentarios del Código Civil español" de Florencio García Goyena, cuya obra fue conocida en nuestro país antes de la redacción defini-

50 Capitant (1930) p. 261. Gaudemet (1965) pp. 414-416. Pillebout (1971) p. 7. Carbonnier (2004) p. 2245, el autor menciona expresamente los artículos 1612 y 1653. En el mismo sentido, GHESTIN (2001) p. 4. Bénabent (2007) p. 273. Cabe hacer presente que la doctrina también lo desprende a contrario sensu del artículo 1184

51 Ghestin (2001) p. 261. Bénabent (2007) p. 273.

52 Ghestin (2001) p. 264

53 Pillebout (1971) p. 6. Ghestin (2001) p. 4 
tiva del Proyecto de $1853^{54}$. La doctrina ha puesto de relieve que la obra de García Goyena tuvo un valor considerable, para los redactores del Código Civil nacional, porque presentaba un panorama completo de la legislación civil hasta entonces conocida ${ }^{55}$.

Hemos acudido a este proyecto porque se advierte una conexión del tenor del artículo 1552 con el referido proyecto, ya que existe una norma equivalente en el artículo 1100 del Código Civil español ${ }^{56}$.

Si nos situamos en las "Concordancias, motivos y comentarios del Código Civil" de García Goyena, el artículo 1007 es la norma equivalente a nuestro artículo 1552 y en sus incisos finales dispone: "En las obligaciones recíprocas, ninguno de los contratantes incurre en mora, si el otro no cumple ó no se allana á cumplir debidamente la obligación que le es respectiva.

Cuando hay mora, por parte de los dos contratantes, perjudica la posterior".

El artículo 1107 -actual artículo 1100 del Código Civil español- regla la constitución en mora del deudor en las obligaciones recíprocas y no la excepción de contrato no cumplido. Teniendo presente lo anterior, resulta relevante destacar que García Goyena menciona expresamente el artículo 1907 del Código Civil de Luisiana como fuente en esta parte de la disposición, afirmando que "el que no cumple, mal puede reclamar de otro el cumplimiento, y de consiguiente, constituirle en mora $[\ldots]^{57}$.

Nos parece relevante, antes de continuar con nuestro análisis, precisar ciertos aspectos vinculados con la norma.

Se ha señalado, por parte de la doctrina, que esta disposición pudo haber sido tomada por García Goyena de otros códigos civiles latinoamericanos, teniendo un rol preponderante el nuestro. En este sentido Cristóbal Montes afirma: “[...] aunque el párrafo final del artículo 1.100 del Código Civil arranque del Proyecto de García Goyena en los términos y con las limitaciones antes dichas y aunque es cierto que la casi generalidad de los códigos civiles modernos no formulan una regla especial respecto a la mora en las obligaciones recíprocas, no estará de más señalar que tal singularidad sí aparece en determinados códigos latinoamericanos, todos anteriores al español y que por tanto han podido influir a la hora de plasmar la regla que aparece en nuestra normativa [...]. Así, el Código Civil de Chile (1855), tras establecer en su artículo 1551 los casos en que el deudor incurre en mora, dispone en el artículo 1.609 (sic) que "en los contratos bilaterales, ninguno de los contratantes está en mora dejando de cumplir lo pactado, mientras el otro no lo cumpla por su parte, o

\footnotetext{
54 Lira (1956) p. 75. En la misma dirección Rodríguez Ennes (2006) pp. 705-726. Guzmán (2000) p. 370.

55 Lira (1956) p. 76

56 El artículo 1100 Código Civil español dispone: "Incurren en mora los obligados a entregar o a hacer alguna cosa desde que el acreedor les exija judicial o extrajudicialmente el cumplimiento de su obligación.

No será, sin embargo, necesaria la intimación del acreedor para que la mora exista:

$1^{\circ}$ Cuando la obligación o la ley lo declaren así expresamente.

$2^{\circ}$ Cuando de su naturaleza y circunstancias resulte que la designación de la época en que había de entregarse la cosa o hacerse el servicio, fue motivo determinante para establecer la obligación.

En las obligaciones recíprocas ninguno de los obligados incurre en mora si el otro no cumple o no se allana a cumplir debidamente lo que le incumbe. Desde que uno de los obligados cumple su obligación, empieza la mora para el otro".

57 García Goyena (1852) p. 46.
} 
no se allana a cumplirlo en la forma y tiempo debidos". En idénticos términos se pronuncia el Código Civil de Colombia (1887) en su artículo 1.608 y 1.609, pues sabido es que los colombianos recibieron como propio e hicieron suyo el paradigmático Código chileno de Andrés Bello" (Cristóbal, 1984, pp. 14-15) ${ }^{58}$.

En la doctrina española, si uno busca manifestaciones de la excepción de contrato no cumplido, cobra vigencia principalmente lo preceptuado en el artículo 1502 del Código Civil español y no solo el artículo 1100. En efecto, la última disposición, en rigor su parte final, solo ha generado discusión en la determinación de la constitución en mora, si es automática o si es necesario requerimiento ${ }^{59}$. El artículo 1502 por su parte, que siendo similar a la hipótesis prevista en el artículo 1872 inciso segundo de nuestro Código Civil, faculta al comprador a suspender el pago hasta que el vendedor haga cesar la perturbación, o afiance la devolución del precio en su caso, o se haya estipulado lo contrario. No existe entonces una consagración expresa de la institución ${ }^{60}$.

A partir de lo expuesto precedentemente, resulta claro que la fuente de la norma del Proyecto de García Goyena es el Código Civil de Luisiana. Además, que esta disposición está reglando la constitución en mora en las obligaciones bilaterales. Por esto cobra relevancia determinar si puede el Código Civil de Luisiana ser la fuente directa de lo preceptuado en el artículo 1552 del Código Civil nacional y si en este se consagra o no realmente la excepción de contrato no cumplido.

\section{C) La influencia del Código Civil de la Luisiana}

El Código Civil de la Luisiana ${ }^{61}$ se encuentra dentro de las fuentes del Código Civil nacional, ya que es parte del derecho codificado de su época, que se pudo conocer a través de la Concordance de Saint-Joseph de 1840, o por su traducción castellana de Verlanga

\footnotetext{
58 Cristóbal Montes (1984) pp. 15-16. Siguen expresamente a este autor Cruz (2004) y Fernández URZAINQUi (1997) pp. 429 y ss.

59 Sobre el particular se ha planteado que es necesario distinguir entre obligaciones simultáneas de cumplimiento simultáneo de aquellas cuyo cumplimiento se encuentra separado. En las primeras, en las que funciona el sinalagma funcional, tendría aplicación el inciso final del artículo 1100 y por ello si una de las partes ha cumplido tiene derecho a considerar automáticamente a la otra constituida en mora. Cfr. Albaladejo (1968) pp. 9 y ss. DíEz-Picazo (2008) p. 685. El autor hace presente que en estos casos es lógico que prefiera oponer la excepción de contrato no cumplido.

60 García Cantero (1991). En este sentido Esther Gómez afirma que es positivo que se consagre una regla como esta (artículo 1191 de la Propuesta de modernización del Código Civil español), que reconoce el carácter general que a este remedio ya le viene asignando la doctrina y jurisprudencia española, más allá de los concretos artículos del Código Civil que lo contemplan (arts. 1466, 1500 o 1502 CC). Gómez (2012) p. 48. Lo mismo, Fenoy, quien afirma "El Código Civil no dispone de norma similar, si bien la exceptio non adimpleti contractus y la exceptio non rite adimpleti contractus se fundan, por ejemplo, en las normas generales de los artículos 1124, 1100 in fine CC. En la compraventa, los artículos 1466 y 1502 CC regulan ciertos supuestos en los que se puede suspender el cumplimiento de la propia prestación”, Fenor Picón (2011) p. 1571.

61 Acerca de las fuentes del Código Civil de Luisiana, véase Moréteau (2012) pp. 31-66. El autor, sin desconocer la influencia del Código Civil francés, rescata las fuentes del Código Civil de Luisiana del año 1825 desde sus orígenes, en especial la similitud con el Digeste de la loi civile 1808. Aborda, además, la radical diferencia con el texto del Código de Luisiana del año 1870 y la necesidad de una actual reforma del mismo.

Acerca de la influencia del derecho español en el Código Civil de Luisiana y del derecho romano en la jurisprudencia de Luisiana puede consultarse Semmnes (1873, reimp. 2012) pp. 314-344.
} 
y Muñiz de $1843^{62}$. En efecto, la doctrina nacional ha puesto de relieve la influencia que tuvo en la redacción de nuestro Código Civil, ya que don Andrés Bello lo consideraba un valioso material que figura como uno de los más citados del codificador nacional ${ }^{63}$.

Nuestro análisis se centra ahora en el tenor del artículo 1907 del Código Civil de la Luisiana, teniendo en consideración la referencia que expresa García Goyena en su proyecto; norma que dispone: "En los contratos ó en las acciones recíprocas, la parte que quiera constituir a la otra en mora debe por lo que á ella toca cumplir las obligaciones"64.

Esta norma se sitúa en el Capítulo III relativo en los efectos de las obligaciones, en su sección II sobre las obligaciones de dar. Previamente a él, su artículo 1905 se refiere a las 3 maneras en que el deudor puede constituirse en mora, a saber: "1a Por los términos del contrato, $2^{\text {a }}$ por el requerimiento hecho por la parte, $3^{\text {a }}$ Por efecto de la ley; lo que sucede cuando la violación sola del contrato se declara por ley que constituye al deudor en mora" 65 . El artículo siguiente, el 1906, se refiere al efecto que produce la constitución en mora en las obligaciones de hacer.

De estas disposiciones resulta plausible que toda la regulación se vincula con la mora del deudor, ya sea en las obligaciones de dar, ya en el efecto que produce en las obligaciones de hacer, ya en la constitución en mora en las obligaciones recíprocas. Salta a la vista la similitud del tenor del artículo 1552 de nuestro Código Civil y el artículo 1907 del Código Civil de Luisiana; norma que, además, en su ubicación sigue la misma estructura que el Código de Bello. Por lo anterior, y tras descartar como fuente directa del tenor del artículo 1552 del Código Civil, el Código Civil francés y el Proyecto de García Goyena es que calificamos al artículo 1907 del Código Civil de Luisiana como la fuente directa del artículo 1552.

Conforme a lo preceptuado por el artículo 1552 del Código Civil, si ninguno de los contratantes, en un contrato bilateral, cumple o se allana a cumplir con su obligación en la forma y tiempos debidos, no puede ninguno de ellos ser considerado en mora. Ello en doctrina se ha denominado "compensación en mora". En las líneas que siguen pretendemos diferenciar esta institución de la excepción de contrato no cumplido.

\subsection{LA COMPENSACIÓN EN MORA Y LA EXCEPCIÓN DE CONTRATO NO CUMPLIDO}

Teniendo en cuenta el tenor del artículo 1552 es que usualmente se han superpuestos dos instituciones, a nuestro juicio, diferentes pero relacionadas, ya que ambas son manifestaciones del principio de simultaneidad en el cumplimiento de las obligaciones y cuyos efectos se verifican: si uno de los contratantes no cumple o no se encuentra llano a hacerlo ${ }^{66}$. En el mismo sentido Fernández Urzainqui afirma "La regla del cumplimiento

\footnotetext{
62 La referencia es a los Códigos francés, bávaro, prusiano, austríaco, sardo, de la Luisiana, holandés, del Cantón de Vaud. Se considera que solo tardíamente, para el Proyecto de 1853, alcanzó a emplear el Proyecto de Código Civil de García Goyena y el Código Civil del Perú. Por todos, Guzmán Brito (1982) pp. 420 y ss.

63 Así Guzmán Brito, hace presente la influencia en el Título Preliminar, Guzmán Brito (1994) p. 1371. GuZMán (1982 b) pp. 422-423.

64 Traducción de Verlanga Guerta, \& Muñiz Miranda (1847) p. 105.

65 Verlanga y Muñiz (1847) pp. 104-105.

66 Reconoce que ambos son medios que permiten asegurar la reciprocidad de las prestaciones, CLEMENTE WAYAR (1981) pp. 610-611.
} 
simultáneo determina, entre sus efectos más característicos, de un lado, la inexigibilidad de la prestación debida por uno de los obligados sin que el reclamante haya cumplido la que correlativamente le correspondía (exceptio non adimpleti contractus), y de otro, la imposibilidad de incurrir en mora uno cualquiera de los obligados mientras el otro no cumpla la prestación recíproca a su cargo (compensatio morae), con la consiguiente constitución en mora por el solo cumplimiento de la obligación correlativa" (Fernández, 1997, p. 410) ${ }^{67}$.

Como hemos adelantado, no ha sido inusual que la doctrina nacional y extranjera aluda, al mismo tiempo, a la excepción de contrato no cumplido y a la compensación de mora, incluso en ocasiones indistintamente a una y otra ${ }^{68}$. Sin embargo, creemos que son claramente diferenciables y que ello permitirá precisar los efectos de una y otra ${ }^{69}$ y esto haremos en las líneas que siguen.

En doctrina, la excepción de contrato no cumplido, se ha caracterizado como una negativa provisional, por parte de quien la alega, al cumplimiento forzado de la prestación ${ }^{70}$. De esta forma, la eficacia de la excepción es solo temporal, queda supeditada hasta que la otra parte cumpla con su obligación o se allane a hacerlo. Es desde esta perspectiva que se ha considerado como un mecanismo de defensa del deudor, acreedor de la obligación recíproca, sustentado en el incumplimiento de un contrato bilateral; en principio cualquiera que haya debido ser coetáneo o simultáneo -salvo acuerdo en contrario entre las partes-, con el único límite de la buena fe objetiva ${ }^{71}$.

Es precisamente por lo anterior que se ha considerado que la excepción de contrato no cumplido paraliza la pretensión de cumplimiento y suspende, por ende, la exigibilidad de la prestación correlativa, ya que no se puede exigir el cumplimiento de la obligación mientras no se cumpla con la obligación correlativa, o al menos, se esté dispuesto a hacerlo.

En principio compartimos esta conclusión precisando por una parte, que en rigor -la mayoría de las veces- es el cumplimiento del plazo o su caducidad lo que determina la exigibilidad de la prestación, de manera que no es requisito, de procedencia de la preten-

\footnotetext{
67 Fernández (1997) p. 410.

68 La doctrina nacional, a propósito del tenor del artículo 1552, pasa de la mora al incumplimiento, superponiendo ambas instituciones, por todos Véase Claro (1978) p. 787. Lo mismo puede advertirse en parte de la doctrina española que ante lo preceptuado por el artículo 1100 del Código Civil y a propósito de la constitución en mora en las obligaciones recíprocas, sostiene que en estos casos el deudor puede oponer la excepción de contrato no cumplido. Cfr. Vásquez Iruzubieta. Moisset de Espanés (1999) p. 846. Así se lee, también, en Díez-Picazo "En sí mismo considerado, el art. 1100, in fine, contiene dos reglas. La primera de ellas, que se encuentra en el inciso inicial, parece una aplicación de la excepción de incumplimiento contractual si se prefiere llamarlo así, de compensación de la mora [...]. Díez-Picazo (2008) p. 680.

En Argentina Gastaldi y Centenario señalan que la excepción de contrato no cumplido, en general, está contemplada en el artículo 1201 del CC. "que implica trasladar al campo contractual la noción de la mora y sus efectos en las obligaciones recíprocas, a las que alude el artículo 510 de dicho cuerpo legal [...]”. Los autores sí, más adelante, indican que el artículo 510 está referido a la mora que solo indirectamente se vincula con la excepción de contrato no cumplido. Gastaldi y Centanario (1995) p. 15.

69 Manifestando la conveniencia de separa la excepción de contrato no cumplido y la compensación de la mora, véase Cruz (2004) pp. 119-124.

70 Espín Canovas (1964) pp. 571 y ss. Abeliuk (2010) pp. 947 y ss.

71 Acerca de una noción amplia y objetiva de incumplimiento, véase Vidal Olivares (2007) pp. 41-59. MejíAs Alonzo (2008) pp. 459-478.
} 
sión de cumplimiento, que pruebe el acreedor que ha cumplido o que se encuentra llano a hacerlo. Diferente es que opuesta la excepción de contrato no cumplido se suspenda el cumplimiento de la prestación y, en ese sentido, se afecte la exigibilidad de la misma como un efecto de la excepción ${ }^{72}$. No creemos que la simultaneidad en el cumplimiento de las obligaciones sea exigencia de la exigibilidad en el cumplimiento de las obligaciones emanadas de un contrato bilateral, sin perjuicio de que la excepción de contrato no cumplido encuentre su fundamento en dicho principio. Y por otra parte, no podemos perder de vista que en la mayoría de las obligaciones bilaterales, que tienen lugar en el tráfico jurídico, el cumplimiento no es propiamente simultáneo, ya sea por acuerdo entre las partes o disposición legal; y en ellas, si bien la excepción de contrato no cumplido opera, su alcance es necesariamente limitado, en el sentido que solo podrá oponerla aquel de los contratantes que no ha tenido la obligación de cumplir primero ${ }^{73}$. Lo último también es predicable tratándose la compensación de la mora y podrá, por ende, constituirse en mora al deudor que ha debido cumplir primero.

El principio de cumplimiento simultáneo de las obligaciones bilaterales impone, además, particularidades en la constitución en mora del deudor y nos lleva a la figura de la denominada compensación de la mora, en virtud de la cual en un contrato bilateral no puede considerarse en mora al contratante que no ha cumplido si el otro no lo ha hecho por su parte o se ha allanado a hacerlo, respecto de su obligación correlativa. Pasa entonces a ser requisito constitutivo de la constitución de la mora el cumplimiento de la obligación recíproca $^{74}$, mientras ello no acontezca las moras se neutralizan ${ }^{75}$. En estos casos la compensación ciertamente no es, ni puede serlo, de la mora, sino de las consecuencias que produce el retraso en el cumplimiento, en esta dirección Gema Díez-Picazo afirma: "no es posible la compensación de moras estrictamente entendida, pues en las obligaciones recíprocas, por su especial naturaleza, no existe un retraso del deudor jurídicamente relevante si a pesar de haber vencido su obligación y ser exigible conforme a Derecho el acreedor no puede efectivamente exigirla porque no cumple con el requisito previo que es su anterior cumplimiento"76 (Díez-Picazo, 1996, pp. 560-561).

72 Cruz (2004) pp. 81-92. En la doctrina nacional Alcalde Silva no considera a la simultaneidad como requisito de exigibilidad de las obligaciones recíprocas proporcionando distintos argumentos para ello. Sin embargo, concluye que la reciprocidad es una exigencia del cumplimiento forzado y de la indemnización de perjuicios, porque estos remedios buscan restablecer cuantitativamente el patrimonio del contratante afectado, manteniendo el carácter de título de atribución del propio contrato incumplido; mas no es necesaria su concurrencia cuando lo que se busca es determinar la exigibilidad de las obligaciones o disolver el vínculo obligatorio a través de la resolución. Cfr. Alcalde Silva (2011) pp. 49-55.

En cambio, Jorge Baraona considera que la simultaneidad es un requisito de exigibilidad en las obligaciones recíprocas emanadas de un contrato bilateral. Cfr. BARAONA (2008) pp. 380-382.

73 En la misma dirección, Cruz (2004) p. 123. Baraona (1998) pp. 313-315.

74 Cfr. Fernández (1997) pp. 429 y ss.

75 En este sentido Izquierdo Tolsada (2001) p. 136. El autor indica que ello conlleva a que no se produzcan los efectos a que daría lugar el instituto de la mora si se tratase de obligaciones simples.

76 Díez Picazo Giménez (1996) pp. 560-561. Fernández (1997) pp. 430-431. En sentido similar Cruz Moreno afirma que en verdad no hay en estos casos una "compensación de la mora" "sino más bien imposibilidad -en tanto dure a su vez la situación de inejecución de la contraobligación que pesa sobre el que la pretende- de constituirla”. CRUz (2004) p. 120 
Como adelantábamos el efecto que produce la "compensación de la mora" es impedir que la mora se produzca, y por ello, naturalmente proyecta sus efectos en todo mecanismo de tutela del acreedor lesionado por el incumplimiento que, para su procedencia, exija la constitución en mora del deudor. Creemos que ello solo acontece con la indemnización de perjuicios, no obstante discutirse su real alcance en una indemnización de perjuicios moratorias y una compensatoria, tema que entre nosotros no es del todo pacífico. El Código Civil nacional es bastante claro al respecto, en su artículo 1557 que dispone: "Se debe indemnización de perjuicios desde que el deudor se ha constituido en mora, o si la obligación es de no hacer, desde el momento de la contravención”.

Desde otra perspectiva, por cierto vinculada, la compensación de la mora se relaciona con la purga de la mora, entendida como una forma de destruir sus efectos. Tradicionalmente una de ellas se presenta si el deudor ofrece la suma debida o se muestra propicio a cumplir con su obligación ${ }^{77}$.

Sin perjuicio de que estos institutos puedan interactuar ante otros mecanismos de tutela del acreedor lesionado por el incumplimiento, atendida su propia naturaleza y finalidad, que creemos no puede ser obviada, salta a la vista una importante diferencia. Mientras la excepción de contrato no cumplido paraliza la pretensión de cumplimiento, la denominada compensación de la mora impide constituir en mora al deudor, incidiendo directamente en la indemnización de perjuicios. Conforme a lo anterior, descartamos que la mora tenga algún tipo de incidencia en la pretensión de cumplimiento ${ }^{78}$.

La doctrina, además, ha puesto de relieve, como otra diferencia entre la excepción de contrato no cumplido y la "compensación de la mora", que esta opera automáticamente, sin necesidad de intervención judicial; lo que no acontece con la primera ${ }^{79}$.

Concluimos entonces que se trata de instituciones diferentes que tienen en común que se trata de manifestaciones del principio de simultaneidad en el cumplimiento de las obligaciones en los contratos bilaterales.

Finalmente, en este punto, queremos consignar que en todos los proyectos de modernización del derecho de obligaciones y en el nuevo derecho de la contratación la excepción de contrato no cumplido es recogida como un mecanismo más de tutela del acreedor lesionado por el incumplimiento, el derecho de suspensión, y tiende a desaparecer la regulación de la mora en general y en las obligaciones recíprocas ${ }^{80}$.

\footnotetext{
77 Ricci (1900) p. 324. Referido al derecho romano Torrent afirma que la situación de morosidad se extinguía por la purgatio morae, que se producía cuando el deudor ofrecía al acreedor el cumplimiento de la prestación debida con las eventuales usura moratoriae. En estos casos el deudor se libera aunque no acepte esta consignación el acreedor, a menos que tuviera una iusta causa para oponerse. Cfr. Torrent (1995) p. 375. Misma dirección Díez-Picazo (2008) p. 686.

78 Moisset diferenciando claramente la mora de la excepción de contrato no cumplido, sostiene que "el simple retardo en el cumplimiento de una prestación, aunque no sea culposo, es decir aunque no haya mora, faculta a la otra parte a ejercitar los derechos que surgen del artículo 1201 del Código Civil argentino y 1426 del Código peruano, es decir, hacer valer la excepción de contrato no cumplido”. Moisset DE Espanés (2006) p. 154

79 FERnÁndez (1997) p. 442.

80 En España, la Propuesta de Modernización del Código Civil en materia de obligaciones y contratos prevé en su artículo 1191 la suspensión en las relaciones obligatorias sinalagmáticas si la contraparte no ha ejecutado su prestación o no se allana a hacerlo. El retardo queda subsumido en la noción amplia y objetiva de incum-
} 


\subsection{LA EXCEPCIÓN DE CONTRATO NO CUMPLIDO Y SU REAL CONSAGRACIÓN EN EL Código Civil}

Tras el estudio de los antecedentes históricos de la excepción de contrato no cumplido y su diferenciación con la compensación en mora del deudor, nos resulta claro afirmar que el artículo 1552 del Código Civil no consagra expresamente la excepción de contrato no cumplido.

No desconocemos, y de hecho, así lo hemos afirmado en otra oportunidad, que la referida excepción es una clara manifestación del principio de simultaneidad en el cumplimiento de las obligaciones.

Nuestro legislador, fiel a sus fuentes, no la consagró de forma explícita, sin perjuicio de encontrase ella implícitamente recogida en el Código Civil nacional, en el propio artículo 1552 pero también en importantes contratos bilaterales, como tradicionalmente lo ha sostenido la doctrina:

a) En el contrato de compraventa, el comprador tiene la facultad de suspender el pago, conferida por el artículo 1872 inciso $2^{\circ}$, en dos casos, a saber: i) si el comprador fuere turbado en la posesión de la cosa, y ii) si el comprador probare que existe contra ella una acción real de que el vendedor no le haya dado noticia antes de perfeccionarse el contrato.

El artículo 1826, referido a la obligación de entregar la cosa por parte del vendedor, pone énfasis en el carácter simultáneo de este contrato y prevé un derecho análogo al referido, para el vendedor, en el supuesto que mengüe considerablemente la fortuna del comprador, de modo que se halle en peligro inminente de perder el precio. De acontecer ello, no se podrá exigir la entrega sino pagando o asegurando el pago, a pesar incluso de existir un plazo.

b) En el contrato de mandato, el artículo 2159 autoriza al mandatario para desistir de su encargo si el mandante no cumple con su obligación de proveer al mandatario de lo necesario para la ejecución del mandato ${ }^{81}$.

La enunciación de estas disposiciones no es taxativa, lo dicho es sin perjuicio de que puedan advertirse otras disposiciones, a propósito de los contratos bilaterales típicos, que sean también una manifestación del principio que funda a la excepción: el cumplimiento simultáneo de las obligaciones bilaterales.

Entendemos por lo anterior que el artículo 1552 del Código Civil nacional solo está reglando la constitución en mora del deudor en los contratos bilaterales. Además, en el título en el que se encuentra, sobre el efecto de las obligaciones, guarda plena armonía ya que se regula en él además, la incidencia de la mora en la traslación de riesgos (artículo 1550), acto seguido la constitución en mora propiamente tal, en el modelo clásico, de la obligación unilateral (artículo 1551) y en las obligaciones bilaterales (artículo 1552), sin

plimiento. En el mismo sentido en Francia, se sitúa el artículo 160 del proyecto de la Chancellerie y el artículo 1157 del Proyecto Catala.

En términos similares lo prevé el artículo 7.1.3 de los Principios de Unidroit. En la misma dirección lo contempla el artículo III 3:401 del Marco Común de Referencia y el artículo 9:201 de los Principios de Derecho Europeo de los contratos, aunque con variantes respecto al incumplimiento que es previsible.

81 Stitchkin Branover (2009) p. 419. 
perjuicio que el artículo 1557 vincula a la constitución en mora con el momento desde que se debe la indemnización de perjuicios ${ }^{82}$.

Creemos que solo clarificado lo anterior es realmente posible determinar el real alcance que tiene la excepción de contrato no cumplido en el sistema de remedios del acreedor frente al incumplimiento. Nos parece que su confusión con la figura de la "compensación en mora" ha contribuido a la vinculación de esta institución con la indemnización de perjuicios y, de paso, con los requisitos de esta, llevándonos a trasladar los requisitos de procedencia de la indemnización de perjuicios a todo otro mecanismo de tutela del acreedor lesionado por el incumplimiento, generándose un intrincado problema con el otro mecanismo propio de los contratos bilaterales: la resolución por inejecución. Una clara delimitación de las instituciones y una adecuada determinación de los supuestos que, en la práctica, pueden suscitarse, nos permitirá arribar a soluciones armónicas con la estructura de nuestro Código Civil.

\section{CONCLUSIONES}

1. Desde una perspectiva histórica la institución de la excepción de contrato no cumplido es desarrollada en el derecho canónico, vinculada a los juramentos promisorios, como una forma de asegurar su obligatoriedad. Con antelación, en el derecho romano, es posible advertir ciertas manifestaciones concretas, sin que tuviese un carácter general, vinculadas principalmente con la buena fe y no con la noción de causa -en rigor con lo que hoy entendemos como sinalagma funcional-.

2. En el Código Civil francés no existe un texto que consagre en términos generales la excepción de contrato no cumplido. Tampoco es posible advertir una disposición con un contenido equivalente a lo dispuesto por el artículo 1552 del Código Civil nacional. Sin embargo, la doctrina que influyó notablemente en nuestro codificador civil recoge expresamente el principio de ejecución simultánea en el cumplimiento de las obligaciones, fundamento de la excepción de contrato no cumplido. Además, hay una serie de disposiciones, a propósito de los contratos en particular, que implícitamente recogen la institución.

3. El antecedente directo del tenor del artículo 1552 del Código Civil es el Código Civil de Luisiana, su artículo 1907, misma fuente tenida a la vista por García Goyena, como explicita en su proyecto y no el referido proyecto. Esta disposición sí está reglando la constitución en mora del deudor en las obligaciones bilaterales y no la excepción de contrato no cumplido.

4. La excepción de contrato no cumplido y la constitución en mora del deudor son instituciones que se fundan en el cumplimiento simultáneo de las obligaciones, más este no es requisito de exigibilidad de las obligaciones recíprocas emanadas de un contrato bilateral. No obstante, fundarse en el mismo principio y compartir el supuesto de procedencia -si uno de los contratantes no cumple lo pactado o no se encuentra llano a hacerlo- difieren en sus efectos y forma de operar. La excepción de contrato no cumplido suspende temporalmente la pretensión de cumplimiento y su forma pura de operar es mediante una

82 YÚSARI (2012) pp. 79-83. 
excepción en el juicio respectivo. La compensación en mora, por su parte, impide que uno de los contratantes pueda ser considerado en mora mientras no cumpla o se allane a hacerlo y opera de pleno derecho; constitución que se nos presenta vinculada a un mecanismo concreto de tutela del acreedor lesionado: la indemnización de perjuicios.

5. El Código Civil nacional siguiendo a los códigos de su época solo recoge implícitamente la excepción de contrato no cumplido, mas ella no está contenida en el artículo 1552 del Código Civil, esta norma consagra la compensación de la mora en las obligaciones bilaterales. La excepción de contrato no cumplido se encuentra implícitamente contenida en todas las disposiciones que son manifestaciones del principio de simultaneidad en el cumplimiento de las obligaciones bilaterales.

Lograr diferenciar ambas instituciones y su real reconocimiento en el Código Civil nacional permite clarificar los efectos que producen en el sistema de remedios del acreedor frente al incumplimiento.

\section{BIBLIOGRAFÍA CITADA}

Abeliuk Manasevich, René (2010): Las Obligaciones, Tomo II (Santiago, Editorial Jurídica), $1.293 \mathrm{pp}$.

Albaladejo, Manuel (1968): "La mora en las obligaciones recíprocas", Revista Crítica de Derecho Inmobiliario, pp. 9-32.

Alcalde Rodríguez, Enrique (2003): "Acción resolutoria y excepción de contrato no cumplido. Algunas precisiones fundamentales respecto de su ámbito de aplicación", Revista Actualidad Jurídica, vol. 8, pp. 69-93.

Alcalde Silva, Jaime (2011): "El tratamiento de los incumplimientos recíprocos en el derecho chileno", en Carvajal, Patricio; Miglietta, Massimo (edit.), Estudios Jurídicos en homenaje al Profesor Alejandro Guzmán Brito (Milán, Edizioni dell'Orso), pp. 37-86.

Alonso Pérez, Mariano (1967): Sobre la esencia del contrato bilateral (Salamanca, Universidad de Salamanca), 67 p.

Álvarez Vigaray, Rafael (1986): La resolución de los contratos bilaterales por incumplimiento (Granada, Editorial Comares), 300 pp.

Arangio Ruiz, Vincenzo (1954): La compravendita in diritto romano (Napoli, Editorial Dott. Eugenio Jovene), 437 pp.

Aubry, C.; Rau, C. (1871): Cours Droit civil français d'après la method de Zacharie (Paris, L.G.J.M), Tomo 4, 783 pp.

BaraOna, Jorge (2008): "Algunas consideraciones sobre el retraso en el cumplimiento de las obligaciones: su configuración y eficacia, en Carlos Pizarro (edit.), Estudios de derecho civil IV (Santiago, Editorial LegalPublishing.) pp. 369-384.

BaraOna, Jorge (1998): El retraso en el cumplimiento de las obligaciones (Madrid, Editorial Dykinson), $350 \mathrm{pp}$.

Bello, Andrés (1890): Obras Completas de don Andrés Bello, Volumen XIII: Proyecto Inédito de Código civil (Santiago, Impreso por Pedro G. Ramírez), 630 pp.

Bénabent, Alain (2007): Droit Civile: les obligations (Paris, Domat Dorit Privé, 11a edición), 713 pp. 
Boyer, Georges (1924): Recherches Historiques sur la résolution des contrats. Origenes de l'Article 1184 C. Civ. (Paris, Les Presses Universitaires de France), 435 pp.

Burdese, Alberto (2006): "L'eccezione di dolo generale da Aquilio a Labeone", en Garofalo, Luigi (edit.), L'eccezione di dolo generale -diritto romano e tradizione romanistica (Padova, Editorial, Cedam), pp. 91-122.

Camus, E. (1942): Curso de derecho romano y derecho de obligaciones (La Habana, Editorial Universidad de La Habana), 334 pp.

Capitant, Henri (1930): De la causa de las obligaciones (trad. Tarraganto y Contreras, Eugenio, Madrid, Góngora Casa Editorial), 505 pp.

Carbonnier, Jean (2004): Droit Civil (Paris, Presses Universitaires de France), 2.574 pp.

Claro Solar, Luis (1978): Derecho civil chileno y comparado, Tomo X: De las Obligaciones (Santiago, Editorial Jurídica de Chile), 804 pp.

Clemente Wayar, Ernesto (1981): Tratado de la mora (Buenos Aires, Editorial Ábaco de Rodolfo Depalma), 651 pp.

Cristóbal Montes, Ángel (1984): La mora del deudor en los contratos bilaterales (Madrid, Cuadernos Civitas), 185 pp.

Cruz Moreno, María (2004): La Exceptio non Adimpleti contractus (Madrid, Tirant lo Blanch), $186 \mathrm{pp}$.

Cujacci, Jacob (1758): Opera Omnia (1522-1590) (Napoli, Typographia Moriana), Tomo 3, Liber XXIII, $971 \mathrm{pp}$.

Delvincourt, M (1824): Cours de code civil (Paris, Chez Delestre-Boulage, Libraire), Tomo 3, 569 pp.

De la Prida, Manuel (2012): "La excepción de contrato no cumplido: su fundamento y naturaleza jurídica" (Memoria para optar al grado de licenciado en ciencias jurídicas, Pontificia Universidad Católica de Valparaíso), 117 pp.

Dell'Aquila, Enrico (1981): La resolución del contrato bilateral por incumplimiento (Salamanca, Ediciones Universidad de Salamanca), 204 pp.

De Saxoferrato, Bartholus (1996): Commentaria (Roma, Istituto Giuridico Bartolo Da Sassoferrato) Tomo 2, 156 pp.

Díez Picazo Giménez, Gema (1996): La mora y la responsabilidad contractual (Madrid, Editorial Civitas), 618 pp.

Díez-Picazo, Luis (2008): Fundamentos del Derecho Civil Patrimonial (Madrid, Editorial Aranzadi S.A., sexta edición), Vol. II, 1092 pp.

D’Ors, Álvaro (1981): Derecho privado romano (Pamplona, Editorial Universidad de Navarra), $640 \mathrm{pp}$.

Domat, J. (1835): Oeuvre complétes de J. Domat (Paris, Alex-Gobelet, Libraire, novena edición), $530 \mathrm{pp}$.

EsMein (1888): "Le serment promissoire en droit canonique", Nouvelle revue historique de droit français et étranger 12, pp. 248-277.

Espín Canovas, Diego (1964): "La excepción de incumplimiento contractual, Anuario de Derecho civil, No 17, vol. 2: pp. 543-581. 
Fenoy Picón, Nives (2011): "La modernización del régimen del incumplimiento del contrato: propuestas de la Comisión General de Codificación. Parte segunda: los remedios por incumplimiento, Anuario de Derecho civil, No 54, Vol. 4: pp. 1481-1684.

Fernández Urzainqui, Francisco (1997): "La regla de la simultaneidad en el cumplimiento de las obligaciones recíprocas", Revista Crítica de Derecho Inmobiliario, No 639: pp 403-462.

Ghestin, Jacques (2001): "L'exceptio d'inexecution", en Fontaine, Marcel (edit.), Les sanctions de l'inexécution des obligations contractuales, études de droit comparé (Paris, Editorial L.G.D.J) pp. 3-55.

Gaudemet, Eugène (1965): Théorie Générale des obligations (Paris, Sirey), 508 pp.

Gastaldi, José María (1995): Excepción de incumplimiento contractual (Buenos Aires, Editorial LexisNexis), 144 pp.

García Cantero, Gabriel (1991): Comentarios al Código Civil, Tomo XIX, Artículos 1445 a 1541 del Código Civil, Disponible en http://vlex.com/vid/articulo-1-502-257131?ix_ resultado=1.0\&query $\% 5 \mathrm{~Bq} \% 5 \mathrm{D}=\mathrm{Art} \% \mathrm{C} 3 \% \mathrm{ADculo}+1.502$.

García Goyena, Florencio (1852): Concordancias, motivos y comentarios del Código Civil español (Madrid, Imprenta de la Sociedad Tipográfico-Editorial), 479 pp.

Gómez, Esther: (2012): "Los remedios ante el incumplimiento del contrato: Análisis de la Propuesta de Modernización del Código Civil en materia de obligaciones y contratos y comparación con el borrador del Marco Común de Referencia”, Anuario de Derecho Civil, No 55, Vol. 1, pp. 29-102.

Guzmán Brito, Alejandro (1982): Andrés Bello Codificador. Historia de la fijación y codificación del derecho civil en Chile, Tomo I (Santiago, Ediciones de la Universidad de Chile), 469 pp.

Guzmán Brito, Alejandro (1982): Andrés Bello Codificador. Historia de la fijación y codifcación del derecho civil en Chile Tomo II (Santiago, Ediciones de la Universidad de Chile), $436 \mathrm{pp}$.

GuZmán Brito, Alejandro (2009): Estudio de Historia dogmática y sistemática sobre el Código Civil chileno-colombiano (Colombia, Editorial Jurídica Diké), 282 pp.

Guzmán Brito, Alejandro (2000): La Codificación Civil en Iberoamérica siglos XIX y XX (Santiago, Editorial Jurídica de Chile), 624 pp.

Guzmán Brito, Alejandro (1996): Derecho privado Romano I (Santiago, Editorial Jurídica), 802 pp.

Guzmán Brito, Alejandro (1996): Derecho privado Romano II (Santiago, Editorial Jurídica), 790 pp.

GuZmán Brito, Alejandro (2005): Acto, negocio, contrato y causa en la tradición del Derecho Europeo e Iberoamericano (Navarra, Editorial Aranzandi), 477 pp.

Guzmán Brito, Alejandro (1994): "El código Napoleón y el "Código Civil de Chile", en Estudios en honor de Pedro J. Frías (Córdova, Academia Nacional de Derecho y Ciencias Sociales de Córdoba) pp. 1359-1376.

Hernández Tejero, Francisco (1978): Lecciones de Derecho Romano (Madrid, Editorial Facultad de Derecho Universidad Complutense, tercera edición), 408 pp. 
IzQuierdo Tolsada, Mariano (2001): Sistema de responsabilidad civil, contractual y extracontractual (Madrid, Editorial Dykinson), 545 pp.

Jörs, P; Kunkel, W (1937): Derecho Privado Romano (trad. L. Prieto Castro, Barcelona, Editorial Labor S.A), 563 pp.

Labruna Luigui (2006): "Note su eccezione di dolo generale e abuso del diritto nelle vedute dei giuristi classici, en Garofalo, Luigi, L'eccesione di dolo generale. Diritto romano e tradizione romanística (Padova, Cedam), pp. 123-137.

LÉvy, Jean-Philippe; Castaldo, André (2010): Histoire du droit privé (Paris, Dalloz, segunda edición), 1619 pp.

Lira Urquieta, Pedro (1956): El Código Civil chileno y su época (Santiago, Editorial Jurídica de Chile), 105 pp.

Mazeaud, Henri; Mazeaud, Léon; Mazeaud, Jean (1998): Leçons de droit civil (Paris, Editorial Montchrestien).

Mejías Alonzo, Claudia Carolina (2011): El incumplimiento resolutorio en el Código Civil (Santiago, LegalPublishing), 312 p.

Mejías Alonzo, Claudia Carolina (2012): La excepción de contrato no cumplido, en rigor, una manifestación del principio de simultaneidad en el cumplimiento de las obligaciones", en prensa (Actas de las X Jornadas Nacionales de Derecho civil, organizadas por la Pontificia Universidad Católica de Santiago).

Mejías Alonzo, Claudia (2008): "El incumplimiento contractual y sus modalidades”, en Guzmán Brito, Alejandro (edit.), Estudios de Derecho civil III (Santiago, Editorial LegalPublishing) pp. 459-478.

Melich-Orsini, José (1997): Doctrina General del contrato (Caracas, Editorial Jurídica Venezolana), $994 \mathrm{pp}$.

Milone, Filippo (1882): La exceptio doli (generalis): Studio di diritto romano (Napoli, Editorial Ricccardo Marghieri di Gius), 237 pp.

Moréteau, Olivier (2012): "De revolutionibus: The place of the civil code in Louisiana and in the legal universo", Journal of Civil Law Studies, Vol. 5, No 1, pp. 31-66.

Nicolas, R (1872): Étude sur le droit de rétention léfal à Rome et en France (Paris, Editorial Pichon), 346 pp.

Moisset de Espanés, Luis (1999): "La mora en el Código Civil de Paraguay de 1987", Revista de Derecho Privado, vol. No 12: pp. 827-847.

Moisset de Espanés, Luis (2006): La mora en las obligaciones (Buenos Aires, Editorial Zavalia), $391 \mathrm{pp}$.

Ourliac, Paul; De Malafosse, J. (1960): Derecho romano y francés histórico (trad. Manuel Fairén, Barcelona. Editorial Bosch), 619 pp.

Planiol, Marcel; Ripert, Georges (1952): Traité pratique de droit civil français (Francia, L.G.D.J, segunda edición), vol. 7.

Persico, Giovanni (1955): L’eccezione d’inadempimento (Milán, Dott. A. Giuffrè), 245 pp.

Petrucci, Aldo (2006): "Applicazioni della Stipulatio in materia creditizia e problema della causa nel Diritto Romano classico", en Adame Goddard, Jorge (edit.), Derecho civil y romano (México, Universidad Nacional Autónoma de México) pp. 237-262. 
Pillebout, Jean-François (1971): Recherches sur l'exception d'inexécution (Paris, L.G.D.J), 268 pp.

Pothier, Robert J (1821-1824): Oeuvres complètes de Pothier, Tomo III (Paris, Thomine et Fortic, novena edición), 514 pp.

Ricci, Francisco (1900): Derecho civil (trad. Eduardo Ovejero (Madrid, Editorial La España Moderna), 396 pp.

Rodríguez Ennes, Luis (2006): "Florencio García Goyena y la Codificación Iberoamericana", Anuario de Historia del Derecho Español, No 76: pp. 705-726.

Torrent, Armando (1995): Manual de Derecho Privado Romano (Zaragoza, Editorial Librería General), 680 pp.

Salinas Araneda, Carlos (2006): El influjo del Derecho Canónico en el Código Civil de la República de Chile (Valparaíso, Ediciones Universitarias de Valparaíso), 259 pp.

Semmnes, Thomas (1873, reimp. 2012): "History of the Laws of the Laws of Lousiana and of the Civil Law”, Journal of Civil Law Studies, Vol. 5, No 1, pp. 314-344.

Stitchkin Branover, David (2009): El mandato civil (Santiago, Editorial Jurídica, quinta edición), $434 \mathrm{pp}$.

VÁsquez Iruzubieta, Carlos "Comentario al artículo 1100 del Código Civil”, Disponible en: <http://vlex.com/vid/comentario-articulo-codigo-civil-74947444>.

Verlanga Guerta \& Muñiz Miranda (1847): Concordancias entre el Código Civil francés y los códigos civiles estrangeros (Madrid, Imprenta de Antonio Yenes, segunda edición), pp. 328.

VIario, Silvia (2008): “L'eccezione di inadempimento nell Emptio Venditio” Disponible en: <http://paduaresearch.cab.unipd.it/886/1/TESI.pdf>.

Vidal Olivares, Álvaro (2007): "Cumplimiento e incumplimiento contractual en el Código Civil. Una perspectiva más realista”, Revista Chilena de Derecho, o 34, Vol. 1: pp 41-59.

Schulz, Fritz (1960): Derecho romano clásico (trad. José Santa Cruz Teigeiro, Barcelona, Editorial Bosch), 620 pp.

Zimmermann, Reinhard (2001): Roman Law, Contemporary Law, European Law. The civilian tradition Today (Nueva York, Oxford University Press), 197 pp.

Zimmermann, Reinhard (1990): The Law of obligations. Roman foundations of the Civilian Tradition (Nueva York, Oxford University Press), 1241 pp.

Zimmermann, Reinhard; Whittaker, Simon (2000): Good Faith in European Contract Law (Cambridge University Press), 720 pp. 